\title{
Perceptions of water and sugar-sweetened beverage consumption habits among teens, parents and teachers in the rural south-western USA
}

\author{
Julia Meredith Hess ${ }^{1, *}$, Emily A Lilo², Theresa $\mathrm{H} \mathrm{Cruz}^{1}$ and Sally M Davis ${ }^{1}$ \\ 'University of New Mexico Prevention Research Center, Department of Pediatrics, MSC 11 6145, 1 University of \\ New Mexico, Albuquerque, NM 87131, USA: ${ }^{2}$ Division of Health and Exercise Science, Western Oregon \\ University, Monmouth, OR, USA
}

Submitted 5 July 2018: Final revision received 16 November 2018: Accepted 10 January 2019: First published online 8 March 2019

\begin{abstract}
Objective: The present research aimed to describe perceptions and behaviours around the consumption of water and sugar-sweetened beverages (SSB) by youths.

Design: A formative, qualitative study which conducted four focus groups. Transcripts were analysed and themes related to reasons youths drink SSB and water, and conversely do not drink SSB and water, were analysed to reveal thematic clusters around sensory factors, environment and policy, access, marketing and role model influences, and health risks.

Setting: A rural, tri-ethnic community in New Mexico, USA.

Participants: Middle- and high-school students, parents and teachers.

Results: Although youths and adults were aware of the health risks of soda, they did not translate this information to other SSB, including sports drinks and sweetened tea. Moreover, their perceptions of risks of dyes outweighed their concern with sugar. Youths and adults were aware of water's health benefits, but they focused on short-term benefits. Youths and adults perceived water as unappealing. Adults were also concerned with water safety and access.

Conclusions: This formative research has implications for decreasing SSB consumption and simultaneously increasing water intake among youths in rural communities. Addressing unique access and safety concerns related to water in rural communities, as well as increasing awareness of the risks of all types of SSB, can work together in a positive feedback loop to change perceptions and behaviours with long-term health consequences. Specific policy suggestions include strengthening school policies to restrict all types of SSB and water promotion efforts that address access, safety and health benefits.
\end{abstract}

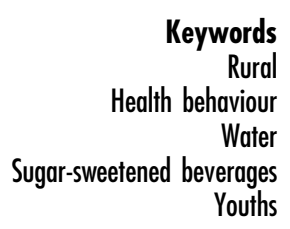

Preventing obesity is a globally recognized public health concern worldwide. Sugar-sweetened beverage (SSB) consumption has been linked to weight gain and obesity in children and adults ${ }^{(1)}$. SSB are a leading source of energy for children in the USA ${ }^{(2)}$. Children aged 2-19 years consume approximately $16 \%$ of their daily total energy as added sugars $^{(3)}$. Children and adults in lower-income households are more likely to consume high levels of SSB than those in higher-income households ${ }^{(4)}$. There is also ample evidence indicating that parental behaviours, home environment and adult role modelling have a substantial impact on youths' SSB consumption behaviours ${ }^{(5-7)}$. Currently, the WHO recommends added sugars be no more than $10 \%$ of total energy $^{(8)}$. This is consistent with US dietary guidelines and recommendations from the Centers for Disease Control and Prevention ${ }^{(9,10)}$. Further, the WHO issued a conditional recommendation based on low-quality evidence that added sugars be less than $5 \%$ of total energy.

A meta-analysis of the effect of SSB on obesity recommends the consumption of healthy alternatives such as water $^{(1)}$. Inadequate water consumption is linked to reduced cognitive functioning and headaches, while increased water intake is associated with improved attention and memory, and fewer dental caries ${ }^{(11)}$. Many children are not adequately hydrated ${ }^{(12)}$ and hydration levels differ by race/ethnicity and income ${ }^{(13)}$.

The Centers for Disease Control and Prevention advocate providing access to safe, free drinking-water 
throughout the school environment ${ }^{(14)}$. In addition, the Healthy Hunger-Free Kids Act states that, 'schools participating in the school lunch program shall make available to children free of charge, as nutritionally appropriate, potable water for consumption in the place where meals are served during meal service ${ }^{(15)}$. Interventions to increase water intake and decrease SSB intake have been implemented in urban schools ${ }^{(16-19)}$, some focusing on increasing water access and others using promotional strategies, with various age groups. One study by Kenney et al. involved a cafeteria-based intervention with signage promoting water and disposable cups placed near dispensers ${ }^{(18)}$. Students in intervention schools nearly doubled their water intake from baseline to follow-up compared with controls. In another study, Muckelbauer et al. paired an educational intervention with the installation of water fountains and found that water consumption increased, although no effects on BMI or SSB consumption were found ${ }^{(19)}$. Brooks et al. found that disparities related to tap water consumption are related to access and perceptions that local sources of tap water are unsafe ${ }^{(13)}$. Additionally, Onufrak et al. found that Hispanic and Black students were more likely to consider school water fountains unclean and unsafe ${ }^{(20)}$.

Much of the research on perceptions of water safety and beverage consumption preferences and habits has been conducted in urban communities ${ }^{(5,21,22)}$. Studies with youths, mostly in urban communities, have found that their beverage decision making tends to be driven by taste, cost, and availability or convenience ${ }^{(23)}$. Students tend to be unconcerned with the health risks of drinking $\mathrm{SSB}$, or if they are aware of the long-term consequences, such as obesity, they do not link these risks to their current behaviours ${ }^{(24)}$. However, little is known about what affects patterns of SSB and water consumption among youths in rural areas.

The present research was conducted to address a gap in the literature regarding beverage consumption among rural youths, particularly American Indian and Hispanic youths, and to inform local implementation efforts. The goal of the research was to gain a more thorough understanding of the perceptions surrounding the safety and appeal of drinking water, SSB preferences and consumption habits, and reasons behind those consumption habits, as well as factors specific to the rural context that might influence beverage choice among youths. The present research is also important as it explores perceptions of both water and SSB, and thus contributes to our understanding of the interrelated factors which can guide efforts to decrease SSB and increase water consumption.

\section{Methods}

The research presented in the current paper was conducted as part of a larger research study, Village
Interventions and Venues for Action (VIVA). The VIVA study focuses on improving access to, and support for, healthy lifestyles in rural New Mexico, USA ${ }^{(25,26)}$. The partner community is in an under-resourced rural area in New Mexico, where only $44.2 \%$ of adults are in the labour force ${ }^{(27)}$. The community has a tri-ethnic (American Indian, Hispanic and Anglo) population. For the years 2012-2016, diabetes death rates for the community were $50 \cdot 3 / 100000$ compared with $21 \cdot 1 / 100000$ for the USA overall $^{(28)}$. For Hispanic and American Indian residents, rates were 65.4/100 00 and 77.8/100000, respectively ${ }^{(29)}$. Working with the university, a local community advisory group identified concern over the high sugar intake through SSB consumption by local residents, particularly youths. We therefore decided to conduct focus groups (FG) in the local middle school and high school, where the population is $68.3 \%$ American Indian, $27.2 \%$ Hispanic and $3.4 \%$ non-Hispanic White. We did not record race/ethnicity of FG participants, but had representation from all groups.

The research team conducted four FG: one with middleschool students, one with high-school students, one with parents and one with teachers, to gain insights on youth behaviours. We included parents and teachers because of their influence on youths, both as role models and because of their control over the home and classroom environments. FG are useful for gathering diverse opinions from groups of people with similar backgrounds and experience $^{(30)}$. The research team developed the semistructured FG discussion guides based on a review of the literature on beverage consumption habits and on research questions. Guides differed slightly for each group (see online supplementary material, Supplemental File 1, Supplemental File 2 and Supplemental File 3 for the student, parent and teacher/staff focus group guides, respectively). The guides were pilot-tested with research staff and youth questions were piloted with middle-school and high-school students unrelated to the research study.

All FG were hosted at the middle school or high school. We began the student FG by asking participants to write down the number of SSB they drank in a day and how much water they drank per day (estimating ounces). We collected the data and read out the range to the group. We then initiated the discussion by stating that research shows that two out of three teens in the USA have one SSB daily ${ }^{(31)}$ and asked for their reactions. We started the adult FG by asking adults about their own consumption of water and SSB, and then asked how much water and SSB they thought their children or students consumed. We asked youths open-ended questions about what they liked and disliked about drinking SSB and water. We asked all groups what harms they associated with SSB, what would get both adults and youths to drink more water, and access issues with respect to SSB and water. For parents, we asked about the home environment and behaviours regarding SSB and water. For teachers we asked about the 
school environment with respect to SSB and water, including policy and adherence to policy. We showed students a selection of water campaign messages, asked them to rank them in order of preference and then asked them to explain their rankings. The study was approved by the University of New Mexico Health Sciences Center Human Research Protections Office.

Study participants were recruited with the help of the local middle school and high school principals, as well as teachers. Convenience sampling techniques were used. The high school principal invited teachers to stay after a faculty meeting; therefore, the majority of the teachers taught high school, with one teacher who also taught middle school. Parents attending a sports event on campus were invited to participate in the parent group. All focus groups were held on school grounds. All FG were moderated by the first and second authors. The first author has extensive experience in focus group discussions and trained all team members. All groups were attended by two note takers, who recorded who was speaking and a summary of speaker comments, including non-verbal communication, to supplement the transcript.

The total number of FG participants was forty (twentysix females, fourteen males). The FG ranged in size from five to fifteen participants and in length from 40 to $70 \mathrm{~min}$, with a mean duration of $49 \mathrm{~min}$ (see Table 1). Participants were provided with snacks, bottled water and an item valued at \$US 15 or less to compensate them for their time.

The FG sessions were audio-recorded, transcribed verbatim and analysed using the qualitative data analysis software NVivo version 10 (QSR International; 2012). The transcripts were independently coded by two team members into thematic categories based on deductive (from the questions) and inductive (emerging from the data) themes. Codes and sub-codes were discussed, defined and applied to FG transcripts. The hierarchical codebook was organized around research and FG questions about factors related to water and SSB consumption. After one round of coding, we further consolidated inductively produced factors into categories such as 'dangers, risks', 'environment, policy, access' and 'sensory', which were similar across all code categories (e.g. 'Reasons people drink SSB', 'Reasons people do not drink SSB'). Another round of analysis consisted of focused coding to further interpret the data for each subcoding $^{(32)}$. For example, under 'Reasons people do not drink SSB: sensory', we examined all text related to sensory reasons across all FG. Each analyst then wrote a summary memo synthesizing the data, using constant comparison to look for parallels and anomalies across demographic groups. We ran inter-coder reliability analyses and examined coding that had a $\kappa$ coefficient of less than 0.75 to determine if there was incongruence in how we were applying the code or if there was an error in applying the appropriate code to the text. The coders then discussed any disagreement with code application until consensus was reached.

\section{Results}

Four main themes resulted from the data and these themes were often interrelated. They included: (i) Reasons people drink SSB; (ii) Reasons people do not drink SSB; (iii) Reasons people drink water; and (iv) Reasons people do not drink water. There were also interrelated sub-themes that affected beverage choices that included sensory factors, policy and environmental factors, access issues, marketing and role model influences, and perceived shortand long-term health benefits, risks and consequences. Table 2 presents a comparison of these themes with quotes by youths, parents and teachers.

\section{Sensory factors}

Participants cited sensory aspects of SSB as the main reason people are drawn to them. SSB taste better, the bubbles are exciting and the flavour is appealing. One high-school student said, 'There is already health benefits from water that people know about, but they just drink the sweet stuff because of the taste of it.' Parents also described the visual appeal of SSB, which often have bright

Table 1 Numbers of participants in the focus groups conducted among students, parents and teachers from a rural, tri-ethnic community in New Mexico, USA, March-May 2016

\begin{tabular}{lcccl}
\hline Focus group & Total $(n)$ & Female $(n)$ & Male $(n)$ & Grade level $(n)$ \\
\hline Students, middle school & 9 & 5 & 4 & $\begin{array}{l}\text { Grade 6: } 3 \\
\text { Grade 7: } 3\end{array}$ \\
& & & & $\begin{array}{l}\text { Grade 8: } 2 \\
\text { Unknown: } 1\end{array}$ \\
Students, high school & 15 & & & $\begin{array}{l}\text { Grade 10: } 6 \\
\text { Grade 11: } 8\end{array}$ \\
Parents & & & & Grade 12: 1 \\
Teachers & 6 & 5 & 1 & N/A \\
Total & 10 & 6 & 4 & N/A \\
\hline
\end{tabular}

N/A, not applicable. 
Table 2 Comparison of youth, parent and teacher responses to questions about drinking-water and sugar-sweetened beverages (SSB) in the focus groups conducted in a rural, tri-ethnic community in New Mexico, USA, March-May 2016

\begin{tabular}{|c|c|c|c|c|}
\hline Theme & Sub-themes & Youths & Parents & Teachers \\
\hline \multirow[t]{3}{*}{$\begin{array}{l}\text { Reasons people } \\
\text { drink SSB }\end{array}$} & Sensory appeal of SSB & '[SSB] taste better.' & 'Caffeine is addicting.' & $\begin{array}{l}\text { 'Caffeine helps keep us [kids and } \\
\text { teachers] awake.' }\end{array}$ \\
\hline & $\begin{array}{l}\text { Media and marketing } \\
\text { influences }\end{array}$ & $\begin{array}{l}\text { 'Because people think Gatorade is all } \\
\text { cool. I'm just saying. Because people } \\
\text { trying to lose weight shouldn't drink } \\
\text { sports drinks. But if you're not trying to } \\
\text { lose weight then yeah.' }\end{array}$ & $\begin{array}{l}\text { 'That's how they attract you: those colours.' } \\
\text { 'They repeat the commercials over and over.' }\end{array}$ & $\begin{array}{l}\text { Kids drink energy drinks for 'the sense of } \\
\text { strength' and 'energy' }\end{array}$ \\
\hline & Access & $\begin{array}{l}\text { 'I don't know like it depends which one } \\
\text { [water or SSB] is easier to get. If there } \\
\text { is one just sitting right there.' }\end{array}$ & $\begin{array}{l}\text { 'It's the sports seasons too like when the boys } \\
\text { play JV basketball they will have one [a sports } \\
\text { drink] at those basketball games, too.' }\end{array}$ & $\begin{array}{l}\text { 'They aren't supposed to be drinking } \\
\text { [SSB] in the classrooms but the kids ... } \\
\text { It's not enforced. The kids have energy } \\
\text { drinks as a rule. Quite a few of them.' }\end{array}$ \\
\hline \multirow[t]{3}{*}{$\begin{array}{l}\text { Reasons people do } \\
\text { not drink SSB }\end{array}$} & Health risks of SSB & $\begin{array}{l}\text { 'Diabetes that will lead them to dialysis } \\
\text { probably?' }\end{array}$ & $\begin{array}{l}\text { 'It's the dye, the dye. She has already got the, } \\
\text { Corn syrup, corn syrup. The red } 40 \text { the yellow } \\
5 \text { all the dye all the stuff, you know, I mean the } \\
\text { Splenda all the everything they put in there.' }\end{array}$ & $\begin{array}{l}\text { 'A lot of the kids are well aware of } \\
\text { diabetes. Some of them.' }\end{array}$ \\
\hline & Sensory dislikes & $\begin{array}{l}\text { 'It tastes like syrup.' } \\
\text { 'Sometimes it's bitter.' } \\
\text { 'They don't quench your thirst. And then } \\
\text { you are still thirsty.' } \\
\text { Makes you feel 'heavy', 'tired', lethargic }\end{array}$ & None mentioned & $\begin{array}{l}\text { Preferring to consume sugar from other } \\
\text { sources besides beverages: 'I prefer } \\
\text { chocolate.' }\end{array}$ \\
\hline & $\begin{array}{l}\text { Role modelling/ } \\
\text { influences }\end{array}$ & None mentioned & $\begin{array}{l}\text { 'I had a video for my kids in elementary that it } \\
\text { shows the can of soda and drops how many } \\
\text { teaspoons of sugar are in it. And the kids are } \\
\text { like no way, and l'm like yeah, there is that } \\
\text { much sugar in that.' }\end{array}$ & $\begin{array}{l}\text { 'You know negative advertising for sugary } \\
\text { drinks. Posters in the hallways.' } \\
\text { 'And the teachers must be a model.' }\end{array}$ \\
\hline \multirow[t]{5}{*}{$\begin{array}{l}\text { Reasons people } \\
\text { drink water }\end{array}$} & $\begin{array}{l}\text { Short- and long-term } \\
\text { benefits of water }\end{array}$ & $\begin{array}{l}\text { 'We drink water because we are athletes. } \\
\text { Dehydration.' }\end{array}$ & $\begin{array}{l}\text { 'You're not going to gain weight from water right? } \\
\text { So drink as much water as you want!' }\end{array}$ & $\begin{array}{l}\text { 'It makes your body healthy. Because if } \\
\text { you drink more soda your tummy will. } \\
\text { l've experienced that before that if you } \\
\text { drink more soda, then that really } \\
\text { affects you.' }\end{array}$ \\
\hline & Access to good water & $\begin{array}{l}\text { 'I think it depends on where you get the } \\
\text { water from 'cause [the municipal] water } \\
\text { is disgusting.' } \\
\text { 'Yeah where I live, its better.' }\end{array}$ & $\begin{array}{l}\text { 'You have to think about all these other } \\
\text { communities, where some are way out there, } \\
\text { so based on income too, it's different because } \\
\text { they are really low income. And then the more }\end{array}$ & $\begin{array}{l}\text { 'If they [students] see [bottled] water on } \\
\text { my desk they will ask me if it's } \\
\text { unopened, they will ask for it. They like } \\
\text { it.' }\end{array}$ \\
\hline & & & $\begin{array}{l}\text { you come out to [town], there's soda and all } \\
\text { these other drinks. So [in more rural } \\
\text { communities] they drink more water than we } \\
\text { do.' }\end{array}$ & $\begin{array}{l}\text { 'There are kids that ask to go to the water } \\
\text { fountain right outside my class and } \\
\text { they will get some water if they are } \\
\text { thirsty and the room is a little bit too }\end{array}$ \\
\hline & & & $\begin{array}{l}\text { 'The water here is not good. For my family, I } \\
\text { have to spend } 30 \text { dollars or more every month } \\
\text { for bottled water for drinking and cooking.' }\end{array}$ & $\begin{array}{l}\text { hot. Because our heating and cooling } \\
\text { system is all wacko. Or, we have a } \\
\text { basketball court outside so in the } \\
\text { morning and also around lunchtime } \\
\text { they are playing. They come into class } \\
\text { for some water.' }\end{array}$ \\
\hline & $\begin{array}{l}\text { Sensory appeal of } \\
\text { water }\end{array}$ & $\begin{array}{l}\text { 'It quenches your thirst.' } \\
\text { 'It's a lot colder here [at school] ... It } \\
\text { tastes better than like regular tap } \\
\text { water.' }\end{array}$ & $\begin{array}{l}\text { 'For me at work that's what they stressed, like } \\
\text { now I work out in the desert, so we hydrate } \\
\text { and I try to bring that home. Fruits and I try to } \\
\text { bring that and so far it's kind of working, but } \\
\text { they like the flavour water, they really like the } \\
\text { water is clear and everything, but it's just } \\
\text { flavour.' }\end{array}$ & $\begin{array}{l}\text { 'You don't feel lazy. It rinses you out. But } \\
\text { with sugary drinks it just sticks with you } \\
\text { and next thing you know you are } \\
\text { gaining weight. But then water, you are } \\
\text { flushing it out. You are active and } \\
\text { going.' }\end{array}$ \\
\hline
\end{tabular}




\begin{tabular}{ll}
\hline Theme & Sub-themes \\
\hline $\begin{array}{c}\text { Marketing and role } \\
\text { models }\end{array}$ \\
\\
$\begin{array}{c}\text { Reasons people do } \\
\text { not drink water }\end{array}$ & $\begin{array}{c}\text { Sensory dislikes/lack of } \\
\text { sensory appeal }\end{array}$
\end{tabular}

not drink water

\section{sensory appeal}

Health risks of unsafe water

Youths

None mentioned

mentioned

'[Whether I drink water or an SSB depends on] like what I'm craving. I usually don't go for water if there's an alternative like tea or something I'll go alternative

'It's not healthy 'cause it's all dirty, so they don't drink it and get sweeter drinks and all that. They just drink that.'

'I don't drink from the fountain 'cause it always has gross things in it.

Lack of access to water/ too much access to SSB

'It depends on where you get the water from because [community] water is disgusting.'

Messages and strategies to change behaviour
Increase access to water
[We would drink more water] if it tasted good. If it was colder. Easier to access. Like instead of how they have milk
Parents

None mentioned

'And everybody knows: Oh don't drink

[municipal] water. I don't feel safe drinking the water. I mean it was really bad when I was water. I mean it was really bad when I was growing up here. It stains people's teeth. I mean I take baths in water that looked like

'Town water, that's the water that the kids are drinking at school. This is what they are getting here through those fountains. I don't know how long it's been since they or who filters them or whatever but our kids get thirsty and they go to those fountains and it scares me 'cause I'm like, what kind of bacteria are they getting? How many years has it been since it's been filtered?

'Another challenge again going back to the fact that the water is not safe. We don't feel like the water, you know what I mean like if it would be so much easier if you could just go to the tap like a normal, like in the city where you can fill up a cup and not have to worry about buying bottles of water you know. That would be nice. 'So maybe if someone could offer, you know, if the kids had access to know that it that it's free.' cartons [at lunch], they could have water'
'Or maybe refilling like a water bottle like a school water bottle.'
Teachers

One of my peers, a football coach abou

10 years ago. If he sees any of the

football players drink soda, he makes

them do 3 laps. Especially like 3 days before a game. He made them run a whole mile. So, for those 15-16-yearold kiddos. I say if you drink these sugary things, you are not going to perform. Even if I let you guys go and play, you guys are going to have draining on your system and it's going to affect your game.'

'Tasteless.'

'TKids] don't realize the benefit of drinking water. That you need it. To not get dehydrated. They don't know that.'

'The other thing in terms of [the village], I don't drink the water. 'Cause it's had some issues and it's a little bit questionable.'

'I think the main reason kids don't drink water is they have other alternatives. They can bust out the pop, or their friend has some or whatever. And that's why they do that. They come into class for some water.'

'One of the challenges with that is if they are selling it a lot of the kids don't have the money to buy it. But if we just provide the water, I'm sure we will see an increase. Also, if they go through the cafeteria, and we have this on the shelf, I'm sure they will take that:'

'And that's actually true, if they give water out at lunch they will take the water.' 


\begin{tabular}{|c|c|c|c|c|}
\hline Theme & Sub-themes & Youths & Parents & Teachers \\
\hline & $\begin{array}{l}\text { Effective messaging } \\
\text { around SSB }\end{array}$ & $\begin{array}{l}\text { 'Sugar: Not so sweet after all.' } \\
\text { Facilitator: 'Who would work if they } \\
\text { were targeting your classmates or you } \\
\text { guys? Not younger students. Who } \\
\text { would you guys like to see like, who } \\
\text { would convince you?' } \\
\text { Two students together: 'Steph Curry.' } \\
\text { Male: 'Justin Bieber.' }\end{array}$ & $\begin{array}{l}\text { 'The biggest thing that would get them to listen if } \\
\text { you guys tried to make it fun and entertaining. } \\
\text { 'Cause that's what my husband, and high- } \\
\text { school son tells me all of the time, is a lot of } \\
\text { the time they get bored when people give } \\
\text { lectures you know 'cause when all they hear is } \\
\text { talking. But if you show examples and do } \\
\text { presentations and make it fun and get } \\
\text { involved than you know what I mean. You } \\
\text { have them hook, line and sinker ... interesting } \\
\text { and fun.' }\end{array}$ & $\begin{array}{l}\text { 'I was going to say when you have movie } \\
\text { stars and those kind of models for } \\
\text { women, they will see the impact on } \\
\text { them. When you see athletes, in the } \\
\text { case of the guys, a basketball player or } \\
\text { a famous NFL star related to water, like } \\
\text { the milk ads we had several years } \\
\text { back.' } \\
\text { 'I recently went to this media summit over } \\
\text { the weekend and I met people who are } \\
\text { into the movie business in New Mexico. } \\
\text { And I met people who know all those } \\
\text { famous Indian actors and actresses so } \\
\text { Native American. So I will be } \\
\text { contacting them and that would be } \\
\text { neat for them to maybe make a pitch.' }\end{array}$ \\
\hline & $\begin{array}{l}\text { Increased education } \\
\text { regarding harms of all } \\
\text { SSB and benefits of } \\
\text { water }\end{array}$ & $\begin{array}{l}\text { Information that contrasts the risks of } \\
\text { drinking SSB and the benefits of } \\
\text { drinking water }\end{array}$ & $\begin{array}{l}\text { 'Having people like expert people like you guys } \\
\text { coming to the schools and emphasize how } \\
\text { important it is and you came give a } \\
\text { presentation to the kids of something. 'Cause } \\
\text { a lot of the time they are getting it from us as } \\
\text { parents and sometimes it just goes in one ear } \\
\text { and out the other. And sometimes if they get it } \\
\text { from somebody else how important and telling } \\
\text { them what all these other drinks actually do to } \\
\text { them and how it's affecting them and how it's } \\
\text { going to affect them in the future would help to } \\
\text { get them to drink water.' }\end{array}$ & $\begin{array}{l}\text { 'I had a video for my kids in elementary } \\
\text { that it shows the can of soda and drops } \\
\text { how many teaspoons of sugar are in it. } \\
\text { And the kids are like no way, and I'm } \\
\text { like yeah, there is that much sugar in } \\
\text { that.' } \\
\text { 'Teachers and parents need to model } \\
\text { healthy behaviours.' } \\
\text { 'Educate parents as well as children.' }\end{array}$ \\
\hline
\end{tabular}


colours appealing to children. This contrasted with those who said they disliked SSB for sensory reasons. Some students mentioned that SSB were bitter, too sweet, tasted 'like syrup', or after drinking SSB their teeth feel 'rough, like sandpaper'.

All groups described water in the community as unappealing, dirty and unsafe. Participants across all groups agreed that the tap water tastes bad, often referencing chlorine or minerals affecting the taste. Participants stated that the local water stained clothes in the washing machine, said they would not even use it to bathe or cook, and expressed a strong aversion to drinking it. This starkly contrasted with the perceptions of water in some surrounding communities, which participants reported as 'high-quality' and 'delicious'.

Students at the high school reported that most water from school fountains was warm although certain fountains had cold, more appealing water. Students said that if the water was colder, they would be more likely to drink it because warm water makes them feel worse, not better. Students also said that they would prefer cold water to room-temperature SSB for ideal thirst quenching. Everyone reported that temperature makes a difference, colder being better.

Middle- and high-school students also said the fountains were 'dirty' and 'nasty', and described seeing vomit and trash in the fountains which, combined with the warm temperature, meant that students found the water unappealing and unsafe. Parents also expressed concern about school fountain safety, both regarding water quality and fountain cleanliness. Sensory perceptions of water as unappealing (bad tasting or discoloured) led people in the community to perceive that local water is unsafe.

Many participants also reported disliking water in general because it lacks variety. One parent stated, 'It's boring. It doesn't have a kick.' A high-school student said, 'It has no taste. It's just there. It's just plain.' Participants talked about it not satisfying cravings, particularly for sweet things. Mothers in particular reported family members complaining that water is boring and wanting other choices.

Students and teachers also cited the caffeinating effects of SSB as a reason why students drink them: to wake up or to stay awake to do homework. Parents cited the addictive effects, saying that the ingredients go right to the 'pleasure centre of the brain'. Teachers noted seeing students drinking energy drinks for the perceived sense of strength and energy that it gives them. Participants talked about 'craving' soda or certain brands of soda. One parent discussed her efforts to wean herself off SSB, which she used to wake up in the morning:

'First thing I [did was] go to the kitchen and open up a drink of pop and then I get ready and right there I'm awake and out the door. But now it's been about a month ... It used to kill me. I used to have a headache and now it's: oh, I don't need it.'
She reported that her approach was 'gradually going down, like a smoker' referencing quitting other addictive behaviours.

Teachers reported that although students do not drink much water, seemingly preferring other beverages, when appealing water is available, they ask for it. One reported that if she has unopened bottled water on her desk, students will ask if they can have it. The students reported liking water for its thirst-quenching properties, and because it does not leave a film or aftertaste in the mouth, the way soda does. All groups reported needing water, stating that it kept you hydrated and healthy, made you feel active and energized, and kept you from feeling 'lazy'. A few parents talked about enjoying flavoured, sparkling or infused water. Adults also believed that drinking water will help you lose weight and feel better. One teacher said that 'water rinses you out' and another said it was important to drink water because 'you will die' without it.

\section{Access}

Water consumption was discussed in terms of access, specifically that students do not have access to water at lunch. Although there are fountains, water is not served as part of the school lunch, where students are only offered milk. Both parents and students suggested they would drink more water if it was included in lunch service, or if students were provided with bottled water or refillable water bottles at school, rather than relying on drinking from the water fountain. Adults and students were in agreement that water needed to be free, not just cheaper than SSB, to encourage consumption.

Convenience is a big driver of consumption. Parents reported making sure they had bottled water at home so their children could easily grab it to take it with them or put it in the freezer to make it colder. Clean tap water access at home also came up repeatedly, with mixed commentary. Families living in some surrounding communities reported access to safe, good-tasting water. However, in other communities, families get water from springs, wells, ditches and streams, and in some cases do not have any source of running water. Students said that people lacking safe drinking-water just drink SSB instead. A teacher also raised this point, saying that in American Indian communities, water is less accessible and this contributes to SSB consumption. This opinion was countered in the parent FG where someone explained that people living closer to towns are more likely to drink SSB because they can buy them more easily. Parents also see bottled water as being more convenient than tap water because family members can easily grab it to take with them, regardless of whether they have access to clean tap water or not.

\section{Environment and policy}

In terms of the physical environment, students said that they drank water for hydration, because they live in a 
desert. Parents also talked about hydration and living in a desert as a reason to drink water. Student athlete participants also stated that, as a rule, they are expected to drink water when they are at practice. When asked what they liked about SSB, one student commented that they drink whatever they have easy access to, whatever is in their immediate environment. Teachers talked at length about how, despite policies that include not selling sodas on campus and banning them in classrooms, students can readily access SSB, which deters them from drinking water.

The school policy banning sodas does not apply to other SSB, such as sweetened iced teas and sports drinks, which many students indicated were their preferred SSB. Teachers said students are not supposed to drink SSB in classrooms, but the rule was not enforced, several complaining that other teachers are too lenient. In addition, for special activities, SSB including sodas are often sold: 'All these fundraisers for Christmas and Valentine's [Day], there is sodas all over.' Bottled water is sold in vending machines at the middle school but not the high school, and costs over \$US 1, which is more than SSB are generally sold for in the community.

\section{Marketing and role model influences}

Students are guided in their beverage choices by external influences including advertising and the behaviour choices of adults in their lives. These were often discussed together, especially when parents or teachers noted the power of marketing and how they believed marketing had a greater influence on youth behaviour than their own messages. The role of marketing was discussed especially in the context of sports drinks. A male high-school student stated:

'Because people think Gatorade is all cool. I'm just saying. Because people trying to lose weight shouldn't drink sports drinks. But if you're not trying to lose weight then, yeah.'

A parent commented that children 'are confused' because they receive mixed messages about sports drinks, hearing from health providers that they should limit them and from advertising that they are good for you. Parents discussed SSB marketing labels, bright colours and child-eye-level placement on supermarket shelves to appeal to children and felt that pricing incentives with better values for larger sizes leads people to think they are getting a bargain. However, teachers commented that youths might be swayed to stop drinking SSB by advertising that discusses the risks of SSB. As these tactics were discussed, people talked about how water is not interesting and is not marketed by celebrities, reducing its appeal to youths. Students and their parents talked about needing celebrity role models for healthier behaviours, and more water or calorie-free products designed to appeal to them.
Conversely, teachers spoke of the need for advertising the harms of SSB to counteract the positive SSB advertisements that featured athletes and other role models.

Participants also discussed the specific influences of adults on student health behaviours. One teacher relayed a story about a coach who prohibited SSB and would make players run laps if caught with SSB, saying that he believed this had a lasting positive impact on athletes' knowledge and practices. Teachers also raised concerns that the community, parents and teachers themselves were not being good role models or encouraging students to drink water. Parents were discussed as both positive and negative role models, by the students, teachers and the parents themselves. All groups mentioned the need for parental limits on SSB consumption. Many parents stated that they do not drink SSB, but their children do, or they buy SSB for their children, or allow them to have SSB in different contexts outside the home (e.g. sports games, parties, restaurants). Some also seemed to believe the marketing regarding the benefits of sports drinks, or described being swayed to buy SSB because their children pestered them. Students reported that, at home, they drink whatever is available. Some parents talked about struggles with grandparents and extended family who give their children SSB or disregard their rules. Teachers stated that both parents and children need more education on the importance of drinking water, presuming that if they understood associated risks and benefits that they would be more likely to serve as role models.

Influences for drinking water mentioned included media, celebrities, parents, teachers and coaches. Both parents and teachers said that children are more open to education information on health behaviours when they are young.

\section{Health benefits, risks and consequences}

\section{Shorter-term health benefits/risks}

Adult participants were aware of the health benefits of water. They believed water helps with weight control and keeps your body clean and healthy inside and out. They also commented that you can drink as much as you want since it contains no calories.

Students commented that water keeps you hydrated and quenches thirst, focusing on more immediate benefits of water. Water was perceived as good for you, necessary, able to help prevent diabetes and calorie-free. Students described drinking water when exercising to prevent getting cramps as opposed to SSB, which they claimed give you cramps. All groups talked about how water makes your insides feel better, particularly compared with soda, and discussed that when you stop drinking SSB and start drinking water, you may go through withdrawals or cravings for the sugar but will feel better in the end.

Short-term health effects of drinking SSB discussed by participants included that SSB make a person feel bad (e.g. 
full, lethargic ('lazy')). Students also said that sugar leads to weight gain that, in turn, leads to longer-term health effects including obesity. Parents and teachers also discussed soda as addictive. Caffeine was cited as an important factor in SSB consumption, not only for parents and teachers, but students as well, who relied on the caffeine to help them meet the demands of school and work. A teacher added that drinking beverages makes students have to use the bathroom a lot and interferes with learning. Teachers admitted that they do not always drink water because they do not have time to go to the bathroom, leaving them more dehydrated.

\section{Long-term bealth consequences}

Both middle-school and high-school students, when describing the long-term consequences of SSB consumption, focused on diabetes. We did hear from teachers, in particular, that they felt SSB consumption contributed to poor health. One teacher relayed how at the school blood drive, they turned away many students for health reasons, such as 'low iron' and 'high blood pressure' and 'high heart rate'.

Teachers said that students are aware of the health risks because they have seen diabetes in their families. Parents did not mention diabetes, but there was significant discussion regarding dyes in drinks and these seemed to generate a lot of mistrust of SSB as a beverage category. One parent said people do not drink SSB because, 'You know what's in them.' Another followed up by saying that she reads the label. But it was clear from the discussion that it is the unknown danger of dyes and chemicals that was deemed risky.

This was supported by the confusion expressed in the parent group on the safety and harms of SSB alternatives and low-calorie water-like options. Some parents were concerned about the harms of acid from adding things like lemon to water. Other parents were unclear about whether the flavoured and sparkling waters had calories, had sugar, or were safer or healthier for their children than the sugary choices. There was also concern over calorie-free sugar substitutes like Splenda, and questions about whether it counted as sugar, or was healthier than sugar.

One parent described her motivation for cutting back on SSB as needing to take care of herself. Parents also talked about how, when their children learned how much sugar was in soda, they cut back: "My 9-year-old came home, [and said], "Mom, this is how much sugar is in the pop." So, you know, he laid off, backed off the soda.'

\section{Discussion}

Our research provides an understanding of the perceptions of drinking-water safety and appeal and the preferences for, and consumption of, SSB by youths in a rural context in the south-western USA. Study participants were aware of health risks associated with SSB; however, they associated these with soda and not with the SSB they most often reported drinking, namely sweetened iced teas and sports drinks. Moreover, like studies of Hispanic immigrants, adults were more concerned with the 'unnaturalness' of SSB, mentioning specifically their concerns with added dyes over the effects of sugar ${ }^{(5,33)}$. All participants students, parents and teachers - associated drinking SSB with long-term health consequences, including obesity, but most frequently diabetes.

Students were aware of the health benefits of water, but not to the extent that they were aware of the potential harms of soda. Students mentioned that water hydrates you and that this was important in the desert, but like many youths they were not aware that they may be chronically under-hydrated ${ }^{(12)}$. These findings align with research on college students' water consumption which also found perceptions of health benefits associated with water consumption, suggesting that these perceptions should be built upon in campaigns that promote healthy behaviours ${ }^{(23)}$.

Participants had mixed perceptions of the taste and safety of local water supplies, but many disliked the taste and some were concerned with tap water safety. Like their urban counterparts ${ }^{(13)}$, participants discussed water access issues, some similar and some different for rural communities. Participants in our sample came from a variety of communities with varying access to water sources: a village with treated water; more rural areas with well water; and reservation communities that truck in water. Similar to urban areas there was concern with the availability of free water in schools ${ }^{(14)}$, but there was also concern over the lack of, or low density of, stores that sell water in rural communities. As with urban areas, safety concerns were discussed, although they differed by context. The Gold King Mine spill that affected Navajo and other communities in northern New Mexico may have heightened concerns about water safety. We also found that high mineral content and bad-tasting water were sometimes conflated with safety issues. Nevertheless, as other studies have suggested, access to free, tasty sources of drinkingwater is important to address if health advocates want to promote drinking water over $\mathrm{SSB}^{(18)}$. Any initiative to increase water intake by students needs to address these concerns through water filtration and softeners at the schools, combined with promotion of school drinkingwater as safe and tasty. Further, initiatives should address SSB policies in schools. Although there are national polices ${ }^{(34)}$ that address SSB access and schools (e.g. Smart Snacks), and policies at the local (school) level as well, students and teachers noted that these policies were confusing, did not apply to all SSB, or were unevenly or not enforced. Finally, students and parents need more education and information regarding the health risks of their current beverage choices to highlight the risks of behaviours, both helping them to recognize low levels of 
hydration and explaining the high sugar content in sports drinks, flavoured teas and juice drinks.

Conducting formative research with focus populations elicits local concerns and community contexts relevant to intervention development and implementation. In the present study, no concerns were expressed regarding $\mathrm{Pb}$ in the water system, despite a national focus on $\mathrm{Pb}$ contamination following the crisis in Flint, Michigan ${ }^{(35)}$. Instead, there were concerns regarding access to potable drinking-water in homes without municipal water service. Although access to safe, potable drinking-water is considered a basic human right, there continue to be underresourced rural, frontier and tribal communities in the USA without access to water systems, and many schools have also been found to have unsafe water supplies ${ }^{(13,36)}$.

The generalizability of the present study is limited because participants were drawn from student, parent and teachers in one community. However, although these data were exploratory and formative, they add to the literature and may inform initiatives in other similar contexts. The data may also be subject to response bias, although participants did discuss both the positive aspects of SSB and the negative aspects of water.

\section{Implications for future practice}

Perceptions of both water and SSB health risks and access influence consumption practices and thus are an important step in developing evidence-based interventions to change behaviour. The findings from these FG in a rural, tri-ethnic community highlight particular challenges for decreasing SSB consumption and increasing water consumption. Youths were largely unconcerned or unaware of the health risks posed by drinking SSB other than soda, but did associate soda with diabetes and obesity. While students reported feeling better when more hydrated, they did not associate feeling bad with being dehydrated, nor were they moving towards drinking more water regularly.

Adults were more aware of the health risks of SSB and the health benefits of water, but described tap water as an unsafe choice, and expressed confusion regarding many SSB and sugar-free drinks besides soda. While some parents discussed limiting sodas, many reported regularly providing sports drinks and juices to their children and were confused about which beverages were healthiest. Therefore, addressing concerns about water availability and safety, including those particular to rural areas, and educating parents on SSB besides soda are a necessary component to any initiative to increase drinking-water consumption in rural communities.

Further, similar to findings in urban settings, we suggest that in rural settings the inclusion of institutional policies that favour drinking water (e.g. clean fountains with cold water, allowing water bottles in classrooms, providing free water at lunch and restricting access to SSB at school) will reduce barriers to drinking-water consumption, particularly in communities where tap water is perceived as unsafe. Access to free, good-quality drinking-water combined with education about the health effects of water and sugar consumption, and guidance on appropriate limits for SSB, are key to youths choosing water over SSB. Moreover, our findings suggest that behaviour change efforts should focus simultaneously on decreasing SSB consumption and increasing water consumption, as behaviours, home and institutional environments, as well as policies, have mutually reinforcing effects.

\section{Conclusion}

The present qualitative findings provide critical information that can be used to develop culturally and socially appropriate water consumption interventions to address the physical and knowledge barriers rural families face. They provide guidance for strategies to change perceptions and increase awareness about how making simple lifestyle changes can have positive health implications. These insights have already informed several initiatives in the community including a water education curriculum, water testing as part of the middle-school science programme, installation of water-bottle filling stations in the schools and the development of a health communication campaign at the high school. The findings contribute to the research regarding beverage consumption among rural youths and can be used to inform interventions in other similar contexts.

\section{Acknowledgements}

Acknowledgements: The authors would like to thank Alejandro Ortega for his assistance with community engagement, school outreach and data collection. They would like to thank the Cuba High School and Cuba Middle School principals, teachers, parents and students who participated in this research. The authors also appreciate the members of the Step Into Cuba Alliance for their guidance on the expansion of the work in Cuba, New Mexico to include efforts to promote water consumption. Financial support: This journal article is a product of a Health Promotion and Disease Prevention Research Center supported by Cooperative Agreement Number 5U48DP005034 from the Centers for Disease Control and Prevention. The findings and conclusions in this article are those of the authors and do not necessarily represent the official position of the Centers for Disease Control and Prevention. The funder had no role in the design, analysis or writing of this article. Conflict of interest: The authors report no conflicts of interest. Authorship: J.M.H. contributed to designing focus group questions, facilitated/cofacilitated two of four focus groups, analysed the data and co-wrote the manuscript. E.A.L. contributed to designing 
focus group questions, facilitated or co-facilitated four focus groups, analysed the data and co-wrote the manuscript. T.H.C. contributed to the overall design of the healthy living components that were part of the overall study, contributed to focus group question development and co-wrote the manuscript. S.M.D. contributed to the overall design of the healthy living components that were part of the overall study, contributed to focus group question development and co-wrote the manuscript. Ethics of human subject participation: This study was conducted according to the guidelines laid down in the Declaration of Helsinki and all procedures involving human subjects were approved by the University of New Mexico Health Science Center Human Research Review Committee. Written informed consent was obtained from all subjects.

\section{Supplementary material}

To view supplementary material for this article, please visit https://doi.org/10.1017/S1368980019000272

\section{References}

1. Luger M, Lafontan M, Bes-Rastrollo M et al. (2014) Sugarsweetened beverages and weight gain in children and adults: a systematic review from 2013 to 2015 and a comparison with previous studies. Obes Facts 10, 674-693.

2. Reedy J \& Krebs-Smith SM (2010) Dietary sources of energy, solid fats, and added sugars among children and adolescents in the United States. J Am Diet Assoc 110, 1477-1484.

3. Ervin RB, Kit BK, Carroll MD et al. (2012) Consumption of Added Sugar among US Children and Adolescents, 20052008. NCHS Data Brief no. 87. Hyattsville, MD: National Center for Health Statistics; available at https://www.cdc. gov/nchs/data/databriefs/db87.pdf

4. Han E \& Powell LM (2013) Consumption patterns of sugarsweetened beverages in the United States. J Acad Nutr Diet 113, 43-53.

5. Bogart LM, Cowgill BO, Sharma AJ et al. (2013) Parental and home environmental facilitators of sugar-sweetened beverage consumption among overweight and obese Latino youth. Acad Pediatr 13, 348-355.

6. Kassem NO \& Lee JW (2004) Understanding soft drink consumption among male adolescents using the theory of planned behavior. J Behav Med 27, 273-296.

7. Kassem NO, Lee JW, Modeste NN et al. (2003) Understanding soft drink consumption among female adolescents using the Theory of Planned Behavior. Health Educ Res 18, 278-291.

8. World Health Organization (2015) Guideline: Sugars Intake for Adults and Children. Geneva: WHO.

9. US Department of Health and Human Services (2015) Cut Down on Added Sugars. https://health.gov/dietarygui delines/2015/resources/DGA_Cut-Down-On-Added-Sugars. pdf (accessed January 2018)

10. Centers for Disease Control and Prevention (2016) Know Your Limit for Added Sugars. https://www.cdc.gov/nutrit ion/data-statistics/know-your-limit-for-added-sugars.html (accessed January 2018).

11. Armfield JM, Spencer AJ, Roberts-Thomson KF et al. (2013) Water fluoridation and the association of sugar-sweetened beverage consumption and dental caries in Australian children. Am J Public Health 103, 494-500.

12. Stookey JD, Brass B, Holliday A et al. (2012) What is the cell hydration status of healthy children in the USA? Preliminary data on urine osmolality and water intake. Public Health Nutr 15, 2148-2156.

13. Brooks CJ, Gortmaker SL, Long MW et al. (2017) Racial/ ethnic and socioeconomic disparities in hydration status among US adults and the role of tap water and other beverage intake. Am J Public Health 107, 1387-1394.

14. Centers for Disease Control and Prevention (2011) Increasing Access to Drinking Water in Schools. http:// www.cdc.gov/healthyyouth/npao/pdf/Water_Access_in_ Schools.pdf (accessed November 2018).

15. Kaiser Permanente (n.d.) Effective Access to Water in Schools. https://www.cacfp.org/files/6815/1094/7895/ Effective_Access_in_School.pdf (accessed November 2018).

16. Elbel B, Mijanovich T, Abrams C, Cantor J et al. (2015) A water availability intervention in New York City public schools: Influence on youths' water and milk behaviors. $\mathrm{Am}$ J Public Health 105, 365-372.

17. Patel AI, Grummon AH, Hampton KE et al. (2016) A trial of the efficacy and cost of water delivery systems in San Francisco Bay area middle schools, 2013. Prev Chronic Dis 13, E88.

18. Kenney EL, Gortmaker SL, Carter JE et al. (2015) Grab a cup, fill it up! An intervention to promote the convenience of drinking water and increase student water consumption during school lunch. Am J Public Health 105, 1777-1783.

19. Muckelbauer R, Libuda L, Clausen K et al. (2009) Promotion and provision of drinking water in schools for overweight prevention: randomized, controlled cluster trial. Pediatrics 123, e661-e667.

20. Onufrak SJ, Park S, Sharkey JR et al. (2014) Perceptions of tap water and school water fountains and association with intake of plain water and sugar-sweetened beverages. J Sch Health 84, 195-204.

21. Ebbeling C, Feldman H, Osganian S et al. (2006) Effects of decreasing sugar-sweetened beverage consumption on body weight in adolescents: a randomized, controlled pilot study. Pediatrics 117, 673-680.

22. Patel AI, Bogart LM, Uyeda KE et al. (2010) Perceptions about availability and adequacy of drinking water in a large California school district. Prev Chronic Dis 7, A39.

23. Block JP, Gillman MW, Linakis SK et al. (2013) 'If it tastes good, I'm drinking it': qualitative study of beverage consumption among college students. J Adolesc Health 52, 702-706.

24. Croll JK, Neumark-Sztainer D \& Story M (2010) Healthy eating: what does it mean to adolescents? J Nutr Educ 33, 193-198.

25. Davis SM, Cruz TH, Kozoll R et al. (2017) Research to practice: implementing physical activity recommendations. Am J Prev Med 52, 2S3, S300-S303.

26. Davis SM, Cruz TH, Hess JM et al. (2017) Implementing physical activity recommendations in a tri-ethnic rural community through a community-university partnership. Prog Community Health Partnersh 11, 149-159.

27. US Census Bureau, Public Information Office (2013) Selected Economic Characteristics: 2007-2011 American Community Survey 5-Year Estimates. https://factfinder.census. gov/faces/tableservices/jsf/pages/productview.xhtml?src= bkmk (accessed February 2019).

28. Centers for Disease Control and Prevention, National Center for Health Statistics (2018) Underlying Cause of Death 19992017 on CDC WONDER Online Database. http://wonder. cdc.gov/ucd-icd10.html (accessed February 2019).

29. New Mexico Department of Health (2018) Indicator Based Information System. https://ibis.health.state.nm.us/query/ result/mort/MortSarea/AgeRate.html (accessed February 2019). 
30. Krueger RA \& Casey MA (2000) Focus Groups: A Practical Guide for Applied Research, 3rd ed. Thousand Oaks, CA: SAGE Publications, Inc.

31. Ogden CL, Kit BK, Carroll MD et al. (2011) Consumption of Sugar Drinks in the United States, 2005-2008. NCHS Data Brief no. 71. Hyattsville, MD: National Center for Health Statistics; available at https://www.cdc.gov/nchs/data/ databriefs/db71.pdf

32. Charmaz K (2014) Constructing Grounded Theory, 2nd ed. Thousand Oaks, CA: SAGE Publications, Inc.

33. Tovar A, Must A, Metayer N et al. (2013) Immigrating to the US: what Brazilian, Latin American and Haitian women have to say about changes to their lifestyle that may be associated with obesity. J Immigr Minor Health 15, 357-364.

34. US Department of Agriculture (2016) A Guide to Smart Snacks in School. https://www.fns.usda.gov/sites/default/ files/tn/USDASmartSnacks.pdf (accessed November 2018).

35. Hanna-Attisha M, LaChance J, Sadler RC et al. (2016) Elevated blood lead levels in children associated with the Flint drinking water crisis: a spatial analysis of risk and public health response. Am J Public Health 106, 283-290.

36. Balazs CL \& Ray I (2014) The drinking water disparities framework: on the origins and persistence of inequities in exposure. Am J Public Health 104, 603-611. 